Dr. sc. Maja Munivrana Vajda ${ }^{1}$, docentica

Dr. sc. Marta Dragičević Prtenjača ${ }^{2}$, docentica

Dr. sc. Aleksandar Maršavelski ${ }^{3}$, docent

Pravni fakultet Sveučilišta u Zagrebu

\title{
NEKAŽNJAVANJE ŽRTAVA TRGOVANJA LJUDIMA U HRVATSKOJ - PRAVNI STANDARD KAO FIKCIJA ILI STVARNOST $^{4}$
}

\author{
UDK: $35: 342(4)$ \\ Izvorni znanstveni rad \\ Primljeno: 1. 7. 2016.
}

U članku se razmatra jedno od najkompleksnijih pravnih pitanja u kontekstu trgovine ljudima - pitanje nekažnjavanja, tj. nepoduzimanja kaznenog progona prema žrtvama trgovine ljudima koje su ostvarile obilježja kaznenog djela u svezi sa svojom viktimizacijom, odnosno kao rezultat iste. Zaključci su utemeljeni na sveobuhvatnoj analizi tzv. klauzule o nekažnjavanju u obvezujućim međunarodnim dokumentima (Konvenciji Vijeća Europe, Direktivi EU), međunarodnim smjernicama i modelima (npr. Preporuke Visokog povjerenika UN-a za ljudska prava o ljudskim pravima i trgovanju ljudima), te u poredbenom zakonodavstvu i praksi. Dostupna poredbena praksa država ukazuje na nedostatke postojećih pravnih rješenja te na potrebu da se pitanje nekažnjivosti žrtava trgovine ljudima riješi na nedvosmislen način, bilo kroz uvođenje izričite i precizne odredbe o nekažnjavanju ili kroz uspostavu jasnih instruktivnih kriterija za postupanje u takvim slučajevima. Autori predlažu novi model nekažnjavanja i nepoduzimanja kaznenog progona prema žrtvama trgovine ljudima u RH, s ciljem izbjegavanja dodatne viktimizacije žrtava i u skladu s potrebama svakog konkretnog slučaja. Potreban je višedimenzionalan i fleksibilan pristup na temelju jasnih odredbi materijalnog i procesnog kaznenog prava, ali i smjernica koje će tužiteljima i sucima omogućiti da uspostave prikladnu ravnotežu između temeljnih načela hrvatskog pravnog sustava i prava osoba koje valja prvenstveno promatrati kao žrtve, a ne kao počinitelje.

\section{Ključne riječi: trgovanje ljudima, žrtve, počinitelji kaznenih djela, klauzula} o nekažnjavanju

1 Dr. sc. Maja Munivrana Vajda je docentica na Katedri za kazneno pravo Pravnog fakulteta Sveučilišta u Zagrebu (Assistant Professor at Chair of Criminal Law, Faculty of Law, University of Zagreb): maja.munivrana@pravo.hr

2 Dr. sc. Marta Dragičević Prtenjača je docentica na Katedri za kazneno pravo Pravnog fakulteta Sveučilišta u Zagrebu (Assistant Professor at Chair of Criminal Law, Faculty of Law, University of Zagreb):mdragicev@pravo.hr

3 Dr. sc. Aleksandar Maršavelski je poslijedoktorand - predavač na Katedri za kazneno pravo Pravnog fakulteta Sveučilišta u Zagrebu (Postdoctoral Lecturer at Chair of Criminal Law, Faculty of Law, University of Zagreb): aleksandar.marsavelski@pravo.hr

4 Ovaj rad je izrađen u okviru projekta Multidisciplinary Research Cluster on Crime in TransitionTrafficking in Human Beings, Corruption and Economic Crime, financiranog od strane Hrvatske zaklade za znanost. 


\section{UVOD U PROBLEMATIKU}

Žrtve trgovanja ljudima specifična su skupina, koju kao takvu prepoznaju i pružaju joj zaštitu razni međunarodni dokumenti. Direktivom 2012/29/EU o uspostavi minimalnih standarda za prava, potporu i zaštitu žrtava kaznenih djela, žrtve trgovanja ljudima su prepoznate kao specijalna, „ranjiva“ kategorija žrtava kojima se treba posvetiti posebna pažnja. ${ }^{5}$ Tom Direktivom je općenito definirano i da je žrtva svaka ,fizička osoba koja je pretrpjela štetu, uključujući tjelesnu, umnu ili emocionalnu štetu ili ekonomski gubitak koji je izravno uzrokovan kaznenim djelom", ${ }^{6}$ a što je od važnosti za razumijevanje pojma žrtve naročito u kontekstu problematike kojom se bavi ovaj rad. Naime, žrtve trgovanja ljudima mogu se istovremeno pojaviti i kao počinitelji kaznenih djela u svezi s njihovim statusom žrtve, tj. počinjeno kazneno djelo je rezultat njihovog položaja žrtve kaznenog djela trgovanja ljudima. U takvim situacijama, predmnijeva se da žrtva stvarno nema izbora, odnosno ne može nego postupiti na nezakonit način. U tom kontekstu djelovanje žrtve se može promatrati kao djelovanje pod utjecajem sile ili prijetnje trgovaca ljudima, tj. djelovanje pod opasnošću. Takvom interpretacijom žrtva je zaštićena institutom krajnje nužde koja u Hrvatskoj, ovisno o situaciji, može isključivati protupravnost djela ili krivnju žrtve. Međutim, upitno je djeluje li žrtva trgovanja ljudima uvijek u krajnjoj nuždi, tj. mogu li se sve situacije kada žrtve trgovanja ljudima čine kaznena djela podvesti pod ovaj opći institut kaznenog prava.

Uzroci viktimizacije su vrlo različiti, ovisno o situaciji svake žrtve ponaosob. Najčešći uzroci koji utječu na osobu da krene u potragu za „boljim životom“ te da postane žrtva trgovanja ljudima, primjerice u svrhu seksualnog iskorištavanja, jesu: siromaštvo, diskriminacija žena, ${ }^{7}$ nedostatak obrazovanja, nezaposlenost, nedostatak pristupa tržištu rada, itd. ${ }^{8}$ Prema Obradoviću, postoje ,push“ i ,pull“ faktori, tj. čimbenici koji su od utjecaja da se osoba odluči napustiti jedno mjesto i krenuti u nove životne izazove i nepredvidive situacije. ${ }^{9}$ On zaključuje da su ti

5 Directive 2012/29/EU OF THE EUROPEAN PARLIAMENT AND OF THE COUNCIL of 25 October 2012 establishing minimum standards on the rights, support and protection of victims of crime, and replacing Council Framework Decision 2001/220/JHA Official Journal of European Union L 315/57 (OJ L 315/57, 14. studenoga 2012.), čl. 22. st. 3. Direktive; dostupna na: http://eur-lex.europa.eu/legalcontent/EN/TXT/PDF/?uri=CELEX:32012L0029\&from=HR (3. ožujka 2016.).

6 Čl. 2. st. 1. toč. a. Direktive 2012/29/EU.

7 Za više vidjeti: Kovčo Vukadin, I.; Jelenić, D., ,,Trgovanje ljudima: kriminološki i kaznenopravni aspekt“", Hrvatski ljetopis za kazneno pravo i praksu (Zagreb), vol. 10, broj 2 (2003.), str. 665-718.

8 Za više vidjeti: Obradović, V. „Trgovanje ženama i djevojkama u svrhu seksualnog iskorištavanja u BIH“, Policija i sigurnost, 15 (2016.), 5-6, str. 249-263.

9 Ibidem. 
faktori isti kao oni za migracije. ${ }^{10}$ Znači praktički što se tiče faktora (,push “ i „pull“), nema razlike među njima glede onih koji utječu na redovne migracije ljudi i faktora koji utječu na to da osobe postanu žrtve trgovanja ljudima. S druge strane, pravno tretiranje migranta i žrtava trgovanja ljudima, jednom kada su identificirani kao migranti ili pak žrtve trgovanja ljudima, vrlo je različito. Često ih je nemoguce identificirati kao žrtve do konačnog odredišta, a često su tretirane kao kriminalci umjesto kao žrtve, kako u zemljama odredišta, tako i u zemljama tranzicije ili porijekla. ${ }^{11} \mathrm{U}$ zemljama odredišta (ali i tranzicije, odnosno prolaska) protiv takvih osoba često se pokreću postupci zbog nezakonitog ulaska i boravka u tim zemljama ili njihovog ilegalnog radnog statusa, pa nerijetko takve osobe bivaju deportirane u zemlje porijekla. ${ }^{12}$

U kontekstu ove tematike vrlo je važna presuda Europskog suda za ljudska prava, Rantsev protiv Cipra i Rusije, ${ }^{13}$ jer pokazuje da je trgovanje ljudima povreda prava čovjeka i njegovih sloboda. ${ }^{14}$ Njome se u središte pozornosti stavlja upravo žrtva, koja mora biti zaštićena od „etiketiranja i sekundarne viktimizacije“ kao i „kriminalizacije“ njezina sudjelovanja u raznim ilegalnim aktivnostima, dok god je bila žrtvom trgovanja ljudima, ${ }^{15}$ a što se razrađuje i u Direktivi i tzv. , soft law“" dokumentima. U tom kontekstu, Preporuke Visokog povjerenika UN-a za ljudska prava (2002.) pružaju niz elemenata za nekažnjavanje žrtava trgovanja ljudima, a između ostalog se jasno i izrijekom navodi da ,žrtve trgovanja ljudima neće biti pritvorene ili optužene ili kazneno gonjene zbog nezakonitog ulaska ili boravka u zemljama tranzita $i$ odredišta, kao niti za njihovo sudjelovanje u nezakonitim aktivnostima u mjeri u kojoj je takvo postupanje izravna posljedica njihovog položaja kao žrtve trgovanja ljudima“.${ }^{16}$ Preporučuje se i to da države zaštite takve osobe od ponovnog iskorištavanja, te da im osiguraju adekvatnu psihološku pomoć,

10 Ibidem.

11 Working Group on Trafficking in Persons „Non-punishment and non- prosecution of victims of trafficking on persons: administrative and judicial approaches to offence committed in the process of such trafficking" - CTOC/COP/WG.4./2010/4, str. 2.

12 Ibidem.

13 Presuda Europskog suda za ljudska prava Rantsev protiv Cipra i Rusije (Br. zahtjeva 25965/04) od 7. siječnja 2010.

14 Derenčinović, D., ,Nisu na prodaju - o pravima žrtava trgovanja ljudima nakon presude Europskog suda za ljudska prava u predmetu Rantsev protiv Cipra i Rusije“, Godišnjak Akademije pravnih znanosti Hrvatske, vol 1. br. 1 (2010.), str. 58.

15 Ibid., str. 61.

16 The United Nations High Commissioner ... (2002.), str. 3. para. 7. Za više vidjeti: Working Group on Trafficking in Persons „Non-punishment and non-prosecution of victims of trafficking on persons: administrative and judicial approaches to offence committed in the process of such trafficking", CTOC/ COP/WG.4./2010/4, str. 4. i The United Nations High Commissioner for Human Rights Recommended Principles and Guidelines on Human Rights and Human Trafficking, E/2002/68/Add.1.; dostupno na: http://www.ohchr.org/Documents/Publications/Traffickingen.pdf (15. prosinca 2015.). 
čije pružanje neće biti uvjetovano spremnošću te osobe na suradnju u kaznenom ili drugome postupku. ${ }^{17}$

Države imaju razna kaznenopravna uređenja i institute koji bi se, ovisno o situacijama, mogli primijeniti u rješavanju ove problematike. Ta uređenja nisu jedinstvena niti su usklađena, stoga se ovaj problem nastojao prvotno riješiti na međunarodnoj razini, na tzv. „soft law“ dokumentima, te kasnije na regionalnoj razini uvođenjem pravno obvezujućeg standarda, tj. klauzule o nekažnjavanju (tzv. „non-punishment clause“) kako bi se osiguralo nekažnjavanje žrtava trgovanja ljudima za kaznena djela koja počine u svojstvu žrtve.

Svrha navedene klauzule jest izbjegavanje pokretanja postupka (kaznenog, prekršajnog ili druge vrste postupka), odnosno kažnjavanja tih osoba, ${ }^{18}$ i obvezujući je pravni standard za države članice EU te države potpisnice Konvencije Vijeća Europe o suzbijanju trgovanja ljudima (dalje: Konvencija). ${ }^{19}$ Nalazi se u članku 26. Konvencije ${ }^{20}$ te u članku 8. Direktive EU 2011/36/EU o prevenciji i suzbijanju trgovanja ljudima i zaštiti žrtava (dalje: Direktiva). ${ }^{21}$ Članak 26. Konvencije propisuje da „države stranke moraju osigurati mogućnost nekažnjavanja žrtava trgovanja ljudima kada su bile uključene u nezakonite aktivnosti, dok god su bile prisiljene tako postupati“ “. ${ }^{22}$ Kako i na koji se način treba omogućiti nekažnjavanje, pobliže je definirano u Obrazloženju (Explanatory Report) uz Konvenciju koja navodi da „svaka stranka može u skladu s obvezom iz članka 26., kroz kazneno materijalno ili procesno pravo ili putem drugih mjera ${ }^{23}$ omogućiti nekažnjavanje

17 Ibid., str. 3. para. 8.

18 Derenčinović, op. cit. u bilj. 10, str. 61.

19 Konvencija VE o suzbijanju trgovanja ljudima (Council of Europe Convention on Action against Trafficking in Human Beings (CETS No. 197), open for signature in Warsaw on May 16th 2005, and entered into force on February 1st 2008); available at: https://www.coe.int/t/dghl/monitoring/trafficking/ Docs/Convntn/CETS197_en.asp (1. prosinca 2015.) i http://www.coe.int/en/web/conventions/full-list/-/ conventions/rms/090000168008371d (1. prosinca 2015.).

20 čl. 26. Konvencije: „Each Party shall, in accordance with the basic principles of its legal system, provide for the possibility of not imposing penalties on victims for their involvement in unlawful activities, to the extent that they have been compelled to do so". - Ibid.

21 Directive 2011/36/EU OF THE EUROPEAN PARLIAMENT AND OF THE COUNCIL of 5 April 2011, on prevention and combating trafficking in human beings and protecting its victims, and replacing Council Framework Decision 2002/629/JHA, Official Journal of European Union L 101 (OJ L 101, 15. travnja 2011.); Direktivom je zamijenjena Okvirna odluka 2002/629/JHA o borbi protiv trgovanja ljudima.

22 Za više o zaštiti žrtava prema Konvenciji vidjeti: Moslavac, B., ,Zaštita žrtava prema Konvenciji Vijeća Europe o suzbijanju trgovanja ljudima“, Hrvatski ljetopis za kazneno pravo i praksu (Zagreb), vol. 15, broj 1 (2008.), str. 143-175.

23 Više o načinima provedbe klauzule o nekažnjavanju vidjeti: OSCE (Organizacija za sigurnost i suradnju u Europi) - Office of the Special Representative and Co-ordinator for Combating Trafficking in Human Beings - „Policy and legislative recommendations towards the effective implementation of the non-punishment provision with regard to victims of trafficking" - in consultation with the Alliance against Trafficking in Persons Expert Co-ordination Team (2013.); dostupno na: http://www.osce.org/secretariat/1 01002?download=true (15. prosinca 2015.). 
žrtava trgovanja ljudima kada su gore navedeni zakonski uvjeti ispunjeni u skladu s osnovnim načelima svakog nacionalnog pravnog sustava“.${ }^{24}$ Drugim riječima, svakoj pojedinoj državi ostavlja se da odluči kojim će putem i na koji način (putem materijalnog, procesnog prava ili nekim drugim mjerama) provesti konvencijsku klauzulu. Članak 8. Direktive određuje da su države dužne, u skladu sa svojim pravnim sustavom, predvidjeti potrebne mjere kako bi osigurale da nadležna tijela imaju ovlaštenje nepokretanja kaznenog ili prekršajnog postupka ili neizricanja sankcija žrtvama „trgovanja ljudima za njihovo sudjelovanje u kriminalnim aktivnostima koje su bili prisiljeni počiniti, a što je bila izravna posljedica podvrgavanja bilo kojem obliku trgovanja ljudima“ ${ }^{25}$ Ova je norma pravno obvezujuća za sve zemlje članice Europske unije, pa tako i za Hrvatsku, koja pitanje nekažnjavanja žrtava trgovanja ljudima trenutno prvenstveno rješava putem instituta krajnje nužde, ${ }^{26}$ jer ne postoji posebna klauzula u čl. 106. Kaznenog zakona (dalje: KZ). ${ }^{27}$

Drugačija je situacija prema tzv. „soft lawu“ ${ }^{28}$ odnosno neobvezujućim

24 Council of Europe Committee of Ministers, Explanatory Report to the Council of Europe Convention on action against trafficking in human beings, CM(2005)32 Addendum 2 final (3 May 2005), str. 42. para. 274; dostupno na: https://rm.coe.int/CoERMPublicCommonSearchServices/DisplayDCTM Content?documentId=09000016800d3812 (11. prosinca 2015.).

25 Art. 8. Directive 2011/36/EU.

26 Za više vidjeti: GRETA - Report concerning the implementation of the Council of Europe Convention on Action against Trafficking in Human Beings by Croatia- First evaluation round (Strasbourg, 30 November 2011), str. 29.

27 Člankom 106. Kaznenog zakona, Narodne novine br. 125/11, 144/12, 56/15, 61/15, inkriminirano je kazneno djelo trgovanja ljudima.

28 Danas egzistirajući „soft law“ dokumenti jesu Komentar preporuka Visokog povjerenika UN-a za ljudska prava iz 2010. godine - The United Nations High Commissioner for Human Rights Recommended Principles and Guidelines on Human Rights and Human Trafficking - Commentary (2010.); dostupno na: http://www.ohchr.org/Documents/Publications/Commentary_Human_Trafficking_en.pdf (15. prosinca 2015.);

Preporuke Visokog povjerenika UN-a za ljudska prava iz 2002 godine;

Briselska deklaracija o sprečavanju i borbi protiv trgovanja ljudima iz 2002. godine (koja predviđa pružanje pomoći i zaštite žrtvama trgovanja ljudima) - Brussels Declaration on Preventing and Combating Trafficking in Human Beings (2002), str. 10-12; dostupno na: http://www.cfr.org/human-rights/brusselsdeclaration-preventing-combating-trafficking-human-beings/p27797 (15. prosinca 2015.);

Rezolucija Europskog parlamenta o trgovanju ljudima iz 1996. godine u kojoj se poziva države članice da osiguraju društvenu i pravnu pomoć žrtvama i njihovu zaštitu od ucjena ili osveta, u vidu provođenja adekvatnih mjera postavljanjem telefonskih linija putem kojih bi im bilo dostupno savjetovanje na njihovu matičnom jeziku, kao i da osiguraju stručne prevoditelje i tumače na sudovima kako bi pomogli žrtvama, te skloništa za žrtve na teritoriju zemalja domaćina. Također se poziva države članice da odobre žrtvama ostanak na njihovom teritoriju u slučajevima gdje bi vraćanje žrtava u zemlje porijekla moglo ozbiljno ugroziti živote tih ljudi koji su podloženi daljnjem iskorištavanju - The Resolution on trafficking in human beings (Official Journal C 032, 05/02/1996 P. 0088), str. 5. § 26. i 27; dostupno na: http://eur-lex.europa. eu/legal-content/EN/TXT/?uri=CELEX\%3A51995IP0326 (15. prosinca 2015.) i na: http://transcrim. pravo.unizg.hr/wp-content/uploads/2015/legislation/Resolution-on-trafficking-in-human-beings.pdf (15. prosinca 2015.).

Haaška deklaracija o europskim smjernicama za učinkovitim mjerama za sprečavanje i borbu protiv trgovanja ženama radi seksualnog iskorištavanja iz 1997. godine, koja ističe potrebu prikladne pomoći i podrške ženama koje su žrtve takvog trgovanja ljudima - The Hague Ministerial Declaration on European Guidelines for Effective Measures to Prevent and Combat Trafficking in Women for 
preporukama (npr. Preporuke Visokog povjerenika UN-a za ljudska prava), ${ }^{29}$ akcijskim planovima, deklaracijama i rezolucijama, koje pozivaju države da ne procesuiraju žrtve trgovanja ljudima glede njihova nezakonitog ulaska ili boravka na području tih država. ${ }^{30}$ Upravo je to bila temeljna ideja odredbe o nekažnjavanju žrtava trgovanja ljudima, koja se, naročito u Preporukama Visokog povjerenika UN-a za ljudska prava (2002.) ${ }^{31}$ te poslije u pravno obvezujućim dokumentima Konvenciji Vijeća Europe o suzbijanju trgovanja ljudima (2005.) i u Direktivi Europske unije (2011/36/EU) širi i na druga kaznena djela što su ih počinile žrtve trgovanja ljudima (za vrijeme dok su bile žrtve trgovanja ljudima). Kao što je već prije napomenuto, klauzula je istaknuta kao pravni standard u dokumentima Europske unije (dalje: EU) i Vijeća Europe (dalje: VE), no nije propisana kao izričita obveza država stranaka u dokumentima Ujedinjenih naroda (dalje: UN) - Konvencije o organiziranom kriminalu (2000. $)^{32}$ niti u Protokolu za trgovanje ljudima (2000.). ${ }^{33}$ Iako je, dakle, na regionalnoj razini klauzula o nekažnjavanju uspostavljena kao standard, sam način njezine implementacije vrlo je različit u pojedinim državama. Postoje dva temeljna modela njezine provedbe u poredbenom pravu. Jedan je model prisile, odnosno krajnje nužde, dok se drugi model odnosi na uzročnost i naziva se kauzalnim (uzročnim) modelom, o čemu će biti više riječi u narednim poglavljima.

\section{TRGOVANJE LJUDIMA U HRVATSKOJ}

Ova je tematika važna za Hrvatsku i to ne samo s aspekta preuzetih pravnih obveza, već i kao praktično pitanje. Poznato je da je do 2011. godine Hrvatska bila pretežno tranzitna zemlja, ali se nakon te godine njezina uloga mijenja, pa se sve

the Purpose of Sexual Exploitation Ministerial Conference under the Presidency of the European Union, The Hague, 24-26 April 1997, str. 6; dostupna na: http://eur-lex.europa.eu/legal-content/EN/ $\mathrm{TXT} /$ ?uri=CELEX\%3A32003G1029(02) (15. prosinca 2015.).

29 The United Nations High Commissioner for Human Rights Recommended Principles and Guidelines on Human Rights and Human Trafficking, E/2002/68/Add.1.; dostupno na: http://www.ohchr. org/Documents/Publications/Traffickingen.pdf (15. prosinca 2015.).

30 Working Group on Trafficking in Persons „Non-punishment and non-prosecution of victims of trafficking on persons: administrative and judicial approaches to offence committed in the process of such trafficking" - CTOC/COP/WG.4./2010/4, str. 3.

31 The United Nations High Commissioner for Human Rights Recommended Principles and Guidelines on Human Rights and Human Trafficking, E/2002/68/Add.1; dostupno na: http://www.ohchr. org/Documents/Publications/Traffickingen.pdf (15. prosinca 2015.).

32 Konvencija UN-a protiv transnacionalnog organiziranog kriminaliteta - dostupno na: http://www. mvep.hr/hr/vanjska-politika/multilateralni-odnosi0/multi-org-inicijative/ (11. prosinca 2015.). Ibid.

33 Protokol o sprečavanju, suzbijanju i kažnjavanju trgovine ljudima, naročito ženama i djecom) - 
više pojavljuje kao zemlja porijekla ili čak krajnjeg odredišta, ${ }^{34}$ naročito od ulaska u Europsku uniju 2013. godine. ${ }^{35}$ Trgovanje ljudima jest kazneno djelo najčešće međunarodnog karaktera, a Hrvatska je, uz druge zemlje regije (Srbiju, Bosnu i Hercegovinu te Sloveniju) na važnom tranzitnom pravcu, pa je posljednjih godina povećan broj identificiranih žrtava trgovanja ljudima (uz iznimku 2013. godine) ${ }^{36}$ Prema podacima Ministarstava unutarnjih poslova (dalje: MUP) najčešći pravci kretanja trgovaca ljudima su: Ukrajina - Srbija - Bosna i Hercegovina - Hrvatska; Moldavija - Srbija - Bosna i Hercegovina - Hrvatska; Srbija - Hrvatska; Bosna i Hercegovina - Hrvatska; Hrvatska - Slovenija - Austrija - Švicarska; Hrvatska - Slovenija - Italija - Francuska - Španjolska. ${ }^{37} \mathrm{U}$ tom kontekstu vrlo je važno pravilno identificirati žrtve trgovanja ljudima što je jedan od najvećih izazova s kojima se susreću nadležna tijela (na terenu), ponajprije policija. Uočen problem istaknut je i u Izvješću Vlade Republike Hrvatske o implementaciji Konvencije VE o suzbijanju trgovanja ljudima (dalje: Izvješće Vlade RH). ${ }^{38}$ Rješavanje ovog problema bilo je predviđeno jednom od mjera u Nacionalnom planu za sprečavanje trgovanja ljudima 2012. - 2015. ${ }^{39}$ Važnost pravilne identifikacije žrtava trgovanja ljudima povlači za sobom obvezu primjene navedenog pravnog standarda, $\mathrm{tj}$. klauzule. Zanimljivo je da je najveći broj identificiranih žrtava trgovanja ljudima upravo iz Hrvatske (61), zatim iz Bosne i Hercegovine (13), potom Srbije (10). ${ }^{40}$ Od toga je najviše identificiranih žrtava seksualnog iskorištavanja mlađih žena, a tijekom 2008. i 2009. godine zamijećeno je povećanje broja radnog iskorištavanja

34 Vlada Republike Hrvatske - Nacionalni odbor za suzbijanje trgovanja ljudima. „Nacionalni plan za suzbijanje trgovanja ljudima za razdoblje od 2012. do 2015. godine“", od 2012. god., str. 6, dostupno na: http://www.mup.hr/UserDocsImages/nacionalni_programi/trgovanje_ljudima/2012/NACIONALNI\%20 PLAN\%20FINALNO.pdf (11. prosinca 2015.).

35 Informacije dostupne na: http://www.mup.hr/31.aspx (11. prosinca 2015.).

36 Ibidem.

37 Ibidem

38 Izvješće hrvatske Vlade o implementaciji Konvencije VE o suzbijanju trgovanja ljudima (,Report submitted by the Croatian authorities on measures taken to comply with Committee of the Parties Recommendation $\mathrm{CP}(2012) 3$ on the implementation of the Council of Europe Convention on Action against Trafficking in Human Beings"), od 29. siječnja 2014., str. 11; dostupno na: https://www.coe. int/t/dghl/monitoring/trafficking/Docs/CommitteeParties/Reply_REC/CP_2014_3_RR_HRV_en.pdf (11. prosinca 2015.).

39 Ponajviše u pravcu bolje i učinkovitije suradnje Ministarstva unutarnjih poslova (dalje: MUP) s drugim ministarstvima (Ministarstvom zdravlja, Ministarstvom socijalne politike i mladih), pravosudnim (Državno odvjetništvo Republike Hrvatske) i Vladinim tijelima, te nevladinim organizacijama (Hrvatski Crveni križ i druge organizacije civilnog društva). - Vlada Republike Hrvatske - Nacionalni odbor za suzbijanje trgovanja ljudima. „Nacionalni plan za suzbijanje trgovanja ljudima za razdoblje od 2012. do 2015. godine“, od 2012. god., str. 6-8, dostupno na: http://www.mup.hr/UserDocsImages/nacionalni_ programi/trgovanje_ljudima/2012/NACIONALNI\%20PLAN\%20FINALNO.pdf (11. prosinca 2015.).

40 Podaci MUP-a odnose se na promatrano razdoblje od 2002. do 2013. godine. Ukupan broj identificiranih žrtava svih nacionalnosti u tom razdoblju jest 120. Tablica i podaci preuzeti sa: http://www. mup.hr/31.aspx (11. prosinca 2015.). 
(na seoskima imanjima, obrtima i sl.). ${ }^{41}$ Ovi se podaci načelno poklapaju s podacima iz Izvješća Europske komisije iz 2015. godine (dalje: Izvješće EK2015), koji se odnose na identificirane i ,pretpostavljene“442 žrtve. Iz tog Izvješća proizlazi da je u razdoblju od 2010. do 2012. godine bilo najviše identificiranih žrtava u svrhu seksualnog iskorištavanja (njih 19), zatim žrtava trgovanja ljudima u svrhu različitih eksploatacija, primjerice radi činjenja kaznenih djela, prosjačenja i sl. (njih 11), dok je najmanje bilo identificiranih žrtava radi radnog iskorištavanja (2). ${ }^{43}$ S druge strane, glede počinitelja kaznenih djela, prema podacima Državnog zavoda za statistiku (dalje: DZS), proizlazi da trgovanja ljudima u Hrvatskoj gotovo da i nema. Broj počinitelja na godišnjoj razini kreće se ispod pet. U tom smislu je zanimljivo konstatirati da je u razdoblju od 2011. godine do 2014. zabilježeno tek nekoliko slučajeva trgovanja ljudima. Tako je 2011. godine samo jedna osoba bila osuđena za kazneno djelo trgovanja ljudima, ${ }^{44}$ 2012. godine dvije osobe ${ }^{45} 2013$. godine samo jedna, ${ }^{46}$ dok su 2014. godine četiri osobe ${ }^{47}$ bile osuđene za predmetno kazneno djelo. ${ }^{48}$

O primjeni pravnog standarda nekažnjavanja identificiranih žrtava trgovanja ljudima koje su počinile kaznena djela tj. o primjeni klauzule o nekažnjavanju u Hrvatskoj saznaje se iz Izvješća GRETA-e iz 2011. godine ${ }^{49}$ (dalje: Izvješće/11) kojim se razmatrala provedba članka 26. Konvencije. U Izvješću/11 decidirano je navedeno da Hrvatska nije provela kazneni postupak niti su bile podnesene kaznene ili druge optužbe ,protiv osoba koje su identificirane kao žrtve trgovanja ljudima dok god su počinili kaznena djela ili prekršaje u vrijeme kada su bili

${ }^{41}$ Informacije dostupne na: http://www.mup.hr/31.aspx (11. prosinca 2015.).

42 Pojam „pretpostavljene žrtve“ obuhvaća potencijalne žrtve trgovanja ljudima koje su kao takve identificirane tijekom istrage predmetnog kaznenog djela. - EU-Commission Report (Eurostat) - Trafficking in Human Beings (2015.), str. 81; dostupno na: https://ec.europa.eu/anti-trafficking/sites/ antitrafficking/files/eurostat_report_on_trafficking_in_human_beings_-_2015_edition.pdf (11. prosinca 2015.).

43 EU-Commission Report (2015.), str. 86-88, 89-91, 92-94.

44 Državni zavod za statistiku, Statistička izvješća, 1478/2012, Punoljetni počinitelji kaznenih djela, prijave, optužbe i osude, 2011., str. 114, 151; dostupno na: http://www.dzs.hr/ (12. prosinca 2015.).

45 Državni zavod za statistiku, Statistička izvješća 1504/2013, Punoljetni počinitelji kaznenih djela, prijave, optužbe i osude, 2012, str. 143; dostupno na: http://www.dzs.hr/ (12. prosinca 2015.).

46 Državni zavod za statistiku, Statistička izvješća 1528/2014, Punoljetni počinitelji kaznenih djela, prijave, optužbe i osude, 2013., str. 147; dostupno na: http://www.dzs.hr/ (12. prosinca 2015.).

47 Državni zavod za statistiku, Statistička izvješća 1551/2015, Punoljetni počinitelji kaznenih djela, prijave, optužbe i osude, 2014., str. 147; dostupno na: http://www.dzs.hr/ (12. prosinca 2015.).

48 Hrvatska je donijela novi Kazneni zakon 2011. godine, koji je stupio na snagu 2013. Prije toga je kazneno djelo trgovanja ljudima bilo regulirano člankom 175. Kaznenog zakona iz 1997. Narodne novine br. 110/97, 27/98, 129/00, 51/01, 111/03, 190/03, 105/04, 84/05, 71/06, 110/07, 152/08, 57/11.

49 GRETA - Skupina država za borbu protiv trgovanja ljudima, Report concerning the implementation of the Council of Europe Convention on Action against Trafficking in Human Beings by Croatia - First evaluation round (Strasbourg, 30 November 2011), str. 29. 
$\check{z} r t v e ",{ }^{50}$ temeljem primjene čl. 31 . KZ/97 $7^{51}$ kojim je bila regulirana sila ili prijetnja. Neodoljiva sila je isključivala radnju, dok su odoljiva sila i prijetnja, ovisno o okolnostima, bili razlozi isključenja protupravnosti ili oslobođenja od kazne. Danas bi se to pitanje, kao što je već ranije rečeno, razmatralo u okviru krajnje nužde (jer se sila i prijetnja razmatraju pod institutom krajnje nužde). To iz razloga što više nema posebne odredbe KZ-a o sili i prijetnji, a i zato što inkriminacija trgovanja ljudima iz članka 106. KZ-a (ranije članka 175. KZ97) ne sadrži klauzulu o nekažnjavanju žrtava trgovanja ljudima. Upravo je to bio jedan od glavnih prigovora sadržanih i u najnovijem Izvješću GRETA-e iz veljače 2016. godine (dalje: Izvješće/16). Navedeno je kako trenutno pravno rješenje ne smatraju zadovoljavajućim za uspješnu implementaciju čl. 26. Konvencije, nego je potrebno u zakon eksplicitno unijeti klauzulu o nekažnjavanju žrtava trgovine ljudima za njihovo sudjelovanje u nezakonitim aktivnostima u mjeri u kojoj su na to bile prisiljene. Ovo iz razloga što u situacijama krajnje nužde teret dokaza leži na okrivljeniku, te je potrebno provesti suđenje, odnosno postupak, koji može vrlo dugo trajati. Radi uviđanja i preispitivanja opravdanosti GRETA-inih prigovora, tj. može li se institut krajnje nužde učinkovito primijeniti na sve situacije u kojima žrtve trgovanja ljudima čine kaznena djela, potrebno je osvrnuti se na poredbene modele nekažnjavanja, odnosno neprovođenja (kaznenog ili drugog) progona.

\section{POREDBENI I TEORIJSKI MODELI NEKAŽNJAVANJA I NEPODUZIMANJA KAZNENOG PROGONA ŽRTAVA}

U ovom dijelu rada najprije ćemo analizirati opći model krajnje nužde ili prisile, koji ćemo razložiti s obzirom na moguće pravne učinke. Nakon toga slijedi posebni kauzalni model, gdje ćemo opisati i različite kriterije za njegovu primjenu koje nalazimo u poredbenom pravu. Na kraju ćemo se osvrnuti i na ostale modele, čija bi primjena u ovim slučajevima mogla doći u obzir.

\section{Opći model krajnje nužde ili prisile}

Temeljna ideja modela krajnje nužde jest izbjeći kažnjavanje žrtava trgovanja ljudima ukoliko su one bile prisiljene ostvariti obilježja bića određenog kaznenog

50 Gore rečeno o neprocesuiranju žrtava trgovanja ljudima za kaznena djela i prekršaje navedeno je i u Nacionalnom planu donesenom za 2009.-2011. - Ibid., str. 29, paragraf 127.

51 Sada je taj institut sile ili prijetnje reguliran institutom krajnje nužde (sila ili prijetnja su jedan od njezinih načina) i nalazi se u članku 22. KZ-a; u Izvješću se navodi stari čl. 31. KZ97, jer Izvješće datira iz 2011. godine, kada još nije bio na snazi novi Kazneni zakon (tek 2013. godine stupa na snagu, iako je bio donesen 2011. godine). 
djela ili prekršaja. U literaturi se dosad smatralo da ovaj model najviše slijedi tekst čl. 26. Konvencije VE, ${ }^{52}$ međutim, spomenuto posljednje izvješće GRETA-e iz veljače 2016. godine to opovrgava. Europske zemlje koje su uglavnom implementirale ovaj model jesu npr. Austrija, Hrvatska, Danska, Albanija, Slovačka i Bugarska. ${ }^{53}$ Krajnja nužda najčešće postoji kao razlog isključenja protupravnosti ili kao ispričavajući razlog, kako u državama kontinentalno-europske pravne tradicije, tako i u državama koje pripadaju anglosaksonskom pravnom krugu. U potonjim sustavima krajnja nužda predstavlja specifičnu osnovu obrane u postupku: nužda (necessity) i prisila (duress). ${ }^{54} \mathrm{U}$ zemljama civilnog prava oblici krajnje nužde najčešce predstavljaju sastojke negativnih pretpostavki kažnjivosti zbog toga što njezino postojanje ima učinak isključenja određenog elementa kaznenog djela u formalnom smislu: protupravnosti ili krivnje. ${ }^{55}$ Osim navedenih tipičnih posljedica krajnje nužde, moguće je i oslobađanje žrtve od kazne. Dakle, u okviru ovog modela postoje ukupno tri načina da se dođe do željenog rezultata nekažnjivosti žrtve trgovanja ljudima: (a) tako da se isključi protupravnost djela, (b) da se isključi krivnja žrtve, ili (c) da se žrtva oslobodi kazne. Svaki od navedenih učinaka pobliže ćemo objasniti.

Protupravnost djela koje je žrtva trgovanja ljudima počinila u situaciji krajnje nužde u pravilu će biti isključena kada je zlo počinjeno radnjom žrtve trgovanja ljudima manje od zla koje se očekivalo žrtvi ukoliko ne izvrši tu radnju. Tipičan slučaj u kojem postoji očigledna potreba isključenja protupravnosti jest primjer kada je žrtva prisiljena koristiti krivotvorene dokumente. U drugačijoj situaciji, gdje žrtva trgovanja ljudima usmrti drugu osobu u krajnjoj nuždi, ne može se pripisati opravdavajući učinak jer se život smatra najvišim pravnim dobrom, čime se isključuje mogućnost postojanja drugog pretežnijeg interesa. Jedino bi djelovanje žrtve u nužnoj obrani opravdalo ubojstvo. Ipak, primjenjivost krajnje nužde kao razloga isključenja protupravnosti nije uvijek posve jasna jer trgovanje ljudima može uključivati nenasilne metode, u prvom redu prijevaru. Primjerice, postavlja se pitanje što ako je žrtvi trgovanja ljudima obećano da će biti prevezena u inozemstvo uz pomoć krivotvorenih dokumenata radi posla u tekstilnoj industriji, a žrtvu se umjesto toga u inozemstvu prisiljava na prostituciju. Iz potonjeg je primjera vidljivo da u trenutku kada je žrtva koristila krivotvorene isprave još uvijek nije bila ni pod kakvom prijetnjom, što dovodi do neprimjenjivosti instituta

52 Tako i Derenčinović, op. cit. u bilj. 10, str. 63.

53 Derenčinović, D., „Comparative Perspectives On Non-Punishment Of Victims Of Trafficking In Human Beings“, Annales XLVI, N. 63, 2014., p. 13.

54 Vidi LaFave, W. R., Criminal Law, 5th ed., West, pp. 519-520, 552-555.

55 Primjerice, u njemačkom pravu postoje razlozi isključenja protupravnosti (Rechtfertigungsgründe) i ispričavajući razlozi (Schuldausschließungsgründe + Entschuldigungsgründe). Vidi Kristian K., Strafrecht: Allgemeiner Teil (6. izd., 2008.), München, str. 326, 337. 
krajnje nužde. Ipak, kako ne bismo a priori posve eliminirali mogućnost primjene prava na krajnju nuždu, valja razmotriti mogu li se određeni teorijski koncepti u konkretnom slučaju primijeniti kako bi se došlo do opravdavajućeg učinka. Pođimo od pretpostavke da u trenutku kada žrtva ostvaruje obilježja kaznenog djela krivotvorenja isprave već predstoji opasnost jer ako se ona predomisli nakon što je preuzela krivotvorene dokumente koji su za nju bili posebno izrađeni, vrlo je izgledno da će je organizatori trgovanja ljudima oteti ili ubiti zbog toga što oni njezino odustajanje mogu protumačiti kao sumnjičavost i rizik da budu prijavljeni policiji. Ipak, da bi postojala krajnja nužda, kod žrtve mora, između ostalog, postojati volja za spašavanjem. Ako žrtva niti ne zna da djeluje u krajnjoj nuždi, onda je ona u obrnutoj zabludi o okolnostima koje isključuju protupravnost, a takva zabluda prema vladajućem mišljenju ne isključuje kažnjivost djela. ${ }^{56}$ Nadalje, kao problematična točka u nekim državama može se pojaviti zahtjev neskrivljenosti opasnosti, što ga je donedavno predviđao i hrvatski zakonodavac kod opravdavajuće krajnje nužde. ${ }^{57}$ Osim toga, krajnja je nužda primjenjiva samo ukoliko nema mogućnosti alternativnog otklanjanja opasnosti (npr. da žrtva pozove policiju), što će u nekim slučajevima u praksi biti teško dokazati.

Drugi mogući učinak sastoji se u tome da se radnja žrtve trgovanja ljudima označi protupravnom, ali da se žrtvu ne smatra krivom zbog ispričavajućeg učinka krajnje nužde. Žrtva se može ekskulpirati za djelo koje predstavlja približno jednako zlo onome koje je prijetilo odnosno ako počinjeno zlo nije nerazmjerno teže od zla koje je prijetilo. Primjerice, ako se žrtvi trgovanja ljudima prijeti da će je se prisiljavati na težak fizički rad ukoliko ona ne pristane prisiljavati druge žrtve na težak fizički rad, postoje čvrsti argumenti da joj se to ne može moralno predbaciti te da bi je trebalo ekskulpirati. Međutim, postavlja se pitanje kako postupiti u ranije spomenutom primjeru kada se žrtvi prijeti smrću ako ne usmrti drugu žrtvu. U poredbenom pravu ne postoji ujednačen stav treba li takvu žrtvu ekskulpirati ili ne. U zemljama kontinentalno-europskog pravnog kruga to bi uglavnom bilo moguće, dok u common law sustavima uglavnom ne. ${ }^{58} \mathrm{Zbog}$ neujednačenosti u praksi država, niti međunarodno kazneno pravo u ranijoj praksi nije dopuštalo oslobađanje od krivnje za ubojstvo pod prisilom, ${ }^{59}$ međutim, Rimski statut je odstupio od navedene prakse te je propisao isključenje kaznene odgovornosti ako se prisila odnosi na neposredno predstojeću smrt ili trajnu tjelesnu ozljedu. ${ }^{60}$

56 Jedino je sporno u literaturi treba li počinitelja u takvom slučaju kazniti za dovršeno kazneno djelo ili za pokušaj. Vidi Bock, D. (2013.), Wiederholungs- und Vertiefungskurs Strafrecht Besonderer Teil Nichtvermögensdelikte, Springer, Heidelberg, str. 229.

57 Vidi Turković, K. et al., Komentar Kaznenog zakona, Narodne Novine, Zagreb, 2013., str. 46.

58 R v Dudley and Stephens (1884.), 14 QBD 273 DC.

59 Prosecutor v. Erdemović, ICTY, Case No. IT-96-22, 7 October 1997.

60 Čl. 31. st. 1. toč. d. Rimskog Statuta Međunarodnog kaznenog suda. 
Treći mogući učinak jest da se žrtvu trgovanja ljudima osudi za počinjeno kazneno djelo, ali da je se oslobodi od kazne. U Republici Hrvatskoj je Kazneni zakon iz 1997. propisivao oslobođenje od kazne za krajnju nuždu u kojoj je počinjeno jednako zlo onom koje je prijetilo. Fakultativno je oslobađanje od kazne kod prekoračenja granica krajnje nužde i danas propisano u kaznenim zakonodavstvima Bosne i Hercegovine, Crne Gore i Srbije.

U svakom slučaju, kada je riječ o ovom modelu (krajnje nužde) kao glavne primjedbe valja istaknuti njegovu općenitost u reguliranju ovog specifičnog problema te opasnost da se on neće primijeniti i da će žrtva ipak biti tretirana kao počinitelj kaznenog djela. Upravo da bi se izbjegla ova pravna nesigurnost, mnoge su države posegle za posebnim kauzalnim modelom.

\section{Posebni kauzalni model}

Ovaj se model često u literaturi naziva kauzalni ili uzročni model zbog toga što se temelji na ideji da trgovanje ljudima predstavlja uzrok počinjenog kaznenog djela žrtve. Dominaciju ovog modela nalazimo primjerice u Argentini, Cipru, Dominikanskoj Republici, Gruziji, Filipinima, Kosovu, Moldaviji, Rumunjskoj, SAD-u. ${ }^{61}$ Kako bi se zadovoljio kriterij uzročnosti, najčešće se zahtijeva da je djelo počinjeno od strane žrtve izravno povezano s trgovanjem ljudima ${ }^{62}$ On u svakom slučaju podrazumijeva specijalnu odredbu u kojoj se često propisuju i dodatni uvjeti kako bi se isključila odgovornost ili kazneni progon žrtve trgovanja ljudima. Ti uvjeti su u poredbenim zakonodavstvima prilično raznoliki. Kao tipične okolnosti koje u nekim državama dovode do isključenja kaznene odgovornosti, nekažnjavanja ili nepoduzimanja kaznenog progona protiv žrtve trgovanja ljudima navode se sljedeće:

(a) da djelo predstavlja izvršavanje naredbe počinitelja trgovanja ljudima;

(b) da se radi samo o određenim skupinama kaznenih djela (statusna kaznena djela, kaznena djela u vezi s ispravama) ili taksativno nabrojanim kaznenim djelima (prostitucija, protuzakonito prelaženje granice, nezakonit rad, utaja poreza, ropstvo, prisilni rad, prosjačenje, nezakonita trgovina, zlouporaba droga i dr.);

61 Non-punishment and non-prosecution of victims of trafficking in persons: administrative and judicial approaches to offences committed in the process of such trafficking, UN Working Group on Trafficking on Persons, CTOC/COP/ WG.4/2010/4, 9 December 2009, str. 5-6.

Derenčinović, D., „Comparative Perspectives On Non-Punishment Of Victims Of Trafficking In Human Beings“, Annales XLVI, N. 63, 2014., str. 15-17. 2.

62 Non-punishment and non-prosecution of victims of trafficking in persons..., op. cit. u bilj. 57., str. 
(c) da se radi o teškom slučaju trgovanja ljudima odnosno da trgovanje ljudima uključuje upotrebu nasilja, prisile ili zlouporabu položaja;

(d) da je žrtva doprinijela identifikaciji, pronalaženju ili uhićenju počinitelja trgovanja ljudima;

(e) da je žrtva trgovanja ljudima dijete (do 18 godina).

Upravo raznolikost navedenih kriterija ukazuje na neujednačenost prakse država, što može neke zemlje učiniti pogodnijim odredištima za trgovce ljudima. Naime, u sredinama u kojima su značajno sužene mogućnosti isključenja kaznene odgovornosti i kažnjavanja žrtve trgovanja ljudima, počinitelji trgovanja ljudima mogu djelovati s većim stupnjem sigurnosti da ih žrtve neće prijaviti.

\section{Ostali modeli}

Prema stajalištu koje zastupa Turković u hrvatskoj literaturi, s obzirom na to da kazneno djelo trgovanja ljudima upravo služi zaštiti žrtava trgovanja ljudima, one se ne mogu kažnjavati. ${ }^{63}$ Derenčinović zaključuje da ova interpretacija upućuje na institut nužnog sudioništva kod kojeg biće kaznenog djela pretpostavlja sudjelovanje više osoba. Pritom primjećuje da biće kaznenog djela trgovanja ljudima $^{64}$ ne pretpostavlja sudjelovanje više osoba: ,ne traži se da je došlo do iskorištavanja druge osobe, odnosno da je ona poduzela bilo koju radnju kojom se ostvaruje biće kaznenog djela [trgovanja ljudima] ... To se u bitnom razlikuje od slučajeva nužnog sudioništva kod kojih se osoba koja sudjeluje u ostvarenju bića djela ne kažnjava (niti kao poticatelj ili pomagač) jer se radi o kaznenom djelu koje služi njezinoj zaštiti“ “. ${ }^{65}$ Valja se složiti da ovdje nema mjesta primjeni instituta nužnog sudioništva. To proizlazi i iz zahtjeva iz čl. 26. Konvencije Vijeća Europe, koji zaštitu žrtava trgovanja ljudima od kaznenog progona ne postavlja samo u odnosu na kazneno djelo trgovanja ljudima, već šire - na poduzimanje mjera od strane države da se te osobe ne kažnjavaju odnosno da se protiv njih ne pokreće kazneni/prekršajni postupak zbog njihovog sudjelovanja u bilo kojim nezakonitim aktivnostima na koje su bile prisiljene uslijed trgovanja ljudima. ${ }^{66}$ Ipak, okolnost da je ovdje isključeno pozivanje na nužno sudioništvo ne znači da se time automatski isključuje mogućnost primjene konvencijskog prava. To valja posebno preispitati.

63 Turković, K., u Novoselec (ur.) i dr., Posebni dio kaznenog prava, Zagreb, 2007., str. 138. (pritom izvodi ovu interpretaciju „na tragu čl. 26. Konvencije VE o suzbijanju trgovanja ljudima“).

${ }_{64}$ Tadašnji čl. 175. KZ/97 (trgovanje ljudima i ropstvo).

65 Derenčinović, op. cit. u bilj. 10., str. 62.

66 Usp. ibid. 
Pri analizi modela izravne primjene čl. 26. Konvencije VE, moramo se osloniti na dvije metode tumačenja pravne norme: tumačenje favor conventionis i tumačenje u duhu europskog prava. Prvo proizlazi iz načela međunarodnog prava da u dvojbi u primjeni određenog pravnog propisa, valja tumačiti sukladno međunarodnom ugovorom koji regulira to područje. U stranoj se literaturi ova metoda tumačenja još naziva international law friendly interpretation ili Völkerrechtfreundliche Auslegung (tumačenje ,prijateljsko“ međunarodnom pravu), pri čemu se ona ne ograničava samo na konvencijsko pravo, već na interpretaciju u skladu s cjelokupnim međunarodnim pravom. Drugo načelo proizlazi iz europskog prava - u literaturi poznato kao „tumačenje prijateljsko europskom pravu“ (u literaturi engleskog i njemačkog govornog područja: European law friendly interpretation ili Europarechtfreundliche Auslegung). Prema tom načelu, ako neka pravna norma koristi izraze koji su poznati u europskom pravu, valja tumačiti te izraze sukladno njihovom određenju u europskom pravu. S obzirom na to da je nacionalno pravosuđe uvijek u dvojbi treba li poduzeti kazneni progon, odnosno kazniti žrtvu trgovanja ljudima za nezakonite radnje koje je počinila, upravo je jedan način da se riješi ova dvojba izravna primjena čl. 26. Konvencije VE. Tome ide u prilog da su u hrvatskom pravnom poretku međunarodni ugovori po rangu iznad zakona koji su potpisani i ratificirani u skladu s Ustavom. ${ }^{67}$

Nešto je drugačija situacija kod modela moguće izravne primjene čl. 8. Direktive, koja je sekundarni izvor prava Europske zajednice i koja bi se, sukladno pravilima europskog prava, mogla primijeniti i izravno od strane suda naročito ako je to u interesu pojedinca, jer su to pravno obvezujući dokumentni i odredbe ne samo za države članice Europske unije, već i za njihove institucije. ${ }^{68}$

\section{IV. (NE)KAŽNJAVANJE ŽRTAVA TRGOVINE LJUDIMA U POREDBENOJ SUDSKOJ PRAKSI}

U prethodnom poglavlju analizirali smo različite poredbene modele nekažnjavanja i nepoduzimanja kaznenog progona prema žrtvi trgovine ljudima koja je počinila kazneno djelo. Kako ovi modeli funkcioniraju u praksi, teško je ocijeniti zbog nedostupnosti podataka, pogotovo tamo gdje formalno nisu pokrenuti kazneni postupci, odnosno gdje nije donesena sudska presuda. Dok je takav ishod

67 Vidi čl. 139-141 Ustava Republike Hrvatske, NN 56/90, 135/97, 8/98, 113/00, 124/00, 28/01, 41/01, 55/01, 76/10, 85/10, 05/14.

68 Za više vidjeti: Rodin, S. i Ćapeta, T., Učinci direktiva Europske unije u nacionalnom pravu s izabranim presudama Europskog suda, u punom tekstu i komentarom, Ministarstvo pravosuđa Republike Hrvatske, Zagreb, 2008., str. 11-57, 57- 59; dostupno na: https://www.pravo.unizg.hr/_download/ repository/Ucinci_direktiva.pdf (15. prosinca 2015.). 
pohvalan s aspekta zaštite žrtava trgovine ljudima, on istodobno onemogućava ili u znatnoj mjeri otežava praćenje i kontrolu postupanja prema žrtvama trgovine ljudima koje su ostvarile obilježja nekog kažnjivog djela. ${ }^{69}$

Tako, primjerice, u Hrvatskoj, utvrdi li nadležni državni odvjetnik kako je djelo počinjeno pod utjecajem neodoljive sile uslijed koje nema kaznenog djela ili pak odoljive sile ili prijetnje koja žrtvu stavlja u situaciju krajnje nužde i posljedično isključenja protupravnosti ili krivnje, odbacit će kaznenu prijavu. ${ }^{70}$ Nisu li, međutim, prisutne stroge pretpostavke navedenih instituta, a o nekim problemima njihove praktične primjene na žrtve trgovine ljudima bilo je već riječi u prethodnom poglavlju (usko tumačenje prisile koja u kontekstu trgovine ljudima može preuzeti suptilnije izričaje, pitanje neskrivljenosti, odnosno nemogućnosti alternativnog otklanjanja opasnosti kod krajnje nužde i sl.), državni odvjetnik načelno mora poduzeti kazneni progon u skladu s načelom legaliteta. ${ }^{71}$ Kao što je već rečeno, prema dostupnim podacima, u Hrvatskoj dosada nije bilo postupaka prema žrtvama trgovanja ljudima, ${ }^{72}$ no nije sasvim jasno, unatoč danom obrazloženju primjene instituta sile, prijetnje odnosno krajnje nužde na kojem temelju je primijenjena klauzula o nekažnjavanju, tj. nepoduzimanju kaznenog progona, jer se ovaj institut (krajnje nužde) primjenjuje u pravilu tek kada je postupak pokrenut.

Relativno bogata sudska praksa razvila se u Ujedinjenom Kraljevstvu, gdje je više žrtava trgovine ljudima procesuirano zbog počinjenih kaznenih djela. U žalbenim postupcima, iskristalizirale su se važne smjernice za tužitelje i sudove. Jedan od najznačajnijih postupaka je onaj protiv L. M., D. G. i M. B., tri žene žrtve trgovine ljudima osuđene zbog sudjelovanja u organizaciji prostitucije, pri čemu su same koristile silu, prijetnju i zlostavljanje. ${ }^{73} \mathrm{U}$ tom je predmetu Kazneni odjel Žalbenog suda Engleske i Walesa razmatrao usklađenost nacionalnog prava s čl. 26.

69 U tom smislu, jedna je od naših preporuka uvođenje posebne evidencije postupanja prema žrtvama trgovanja ljudima kako bi se omogućio nadzor nad stvarnom implementacijom čl. 26. Konvencije odnosno Direktive.

70 Vnučec, Babić, Horjan, Šuperina: „Pravna osnova za odbačaj kaznenih prijava podnesenih od strane policije“, Policija i sigurnost (Zagreb), godina 23. (2014.), broj 1., str. 1-23, str. 4 i 5.

${ }^{71}$ Iznimku predstavlja mogućnost uvjetnog odustanka od progona prema načelu svrhovitosti prema čl. 206.d. ZKP-a koji zbog obaveza koje se žrtvi nameću uglavnom neće biti prikladan u slučaju žrtava trgovine ljudima koje su počinile kakvo (lakše) kazneno djelo. Neuvjetovani odustanak od progona u RH moguć je samo kada je riječ o maloljetnicima - v. čl. 71. Zakona o sudovima za mladež. Kada je riječ o punoljetnim počiniteljima, odbačaj kaznene prijave ili odustanak od kaznenog progona mogući su uz odobrenje Glavnog državnog odvjetnika ako je to razmjerno težini kaznenog djela, ali i značenju iskaza te osobe za otkrivanje i dokazivanje kaznenih djela i članova zločinačke organizacije odnosno udruženja (čl. 206.e. Zakona o kaznenom postupku). Primjena ove odredbe, međutim, načelno nije prikladna na žrtve trgovanja ljudima čiji bi status i sva prava na njegovom temelju trebali biti neovisni o spremnosti na suradnju s tijelima kaznenog progona (u tom smislu v. Derenčinović, D. (2010.), „Nisu na prodaju - o pravima žrtava trgovanja ljudima nakon presude Europskog suda za ljudska prava u predmetu Rantsev protiv Cipra i Rusije“, Godišnjak Akademije pravnih znanosti Hrvatske, Vol. 1, No. 1, str. 53-72, str. 67.

72 Izvješće/11 (GRETA), op. cit. u bilj. 45, str. 29.

73 Regina v. LM; YT; BT; DG, MB [2010.] EWCA Crim 2327. 
Konvencije Vijeća Europe o trgovanju ljudima te je ustanovio kako tri nacionalna mehanizma, uzeta kumulativno, omogućuju poštovanje klauzule nekažnjivosti. ${ }^{74}$ Prije svega, riječ je o isključenju protupravnosti, odnosno o ekskulpirajućem učinku kroz usko shvaćenu krajnju nuždu (u skladu s anglosaksonskim konceptom duress defence), zatim o tužiteljskom diskrecijskom pravu da ne pokrene kazneni progon, te konačno o ovlasti suda da obustavi progon (stay the prosecution) zbog zlouporabe postupka (abuse of process). ${ }^{75}$ Pri tome je sam sud uočio nedostatke modela krajnje nužde (duress) kako zbog zahtjeva prijetnje smrću ili teškom ozljedom, tako i zbog eventualne skrivljenosti, tj. doprinosa opasnosti na strani žrtve ili pak mogućnosti alternativnog otklanjanja opasnosti kroz kontaktiranje javnih tijela ili sl. ${ }^{76}$ Stoga se sud osvrnuo na tužiteljsku diskrecijsku ovlast da ne pokrene postupak te ukazao na tzv. trostupanjsko odlučivanje pri čemu tužitelj mora razmotriti sljedeća tri pitanja:

1) postoje li razlozi vjerovati da je osoba žrtva trgovine ljudima;

2) postoje li dokazi koji upućuju na situaciju krajnje nužde (common law defence of duress);

3) čak i kada ih nema, ali kazneno djelo je vjerojatno počinjeno kao ishod (ekstenzivno tumačene) prisile proizašle iz trgovine ljudima, tužitelj bi trebao razmotriti postoji li javni interes za pokretanjem progona ili ne. ${ }^{77}$

Konačno, ovlast suda da obustavi progon zbog zlouporabe postupka u ovom je kontekstu koncipirana vrlo restriktivno - podnositelj zahtjeva mora dokazati kako tužitelj prilikom donošenja odluke o progonu uopće nije uzeo u obzir navedene smjernice (ili je odluka o pokretanju progona bila očito nerazumna). ${ }^{78}$ Ipak, u razmatranom predmetu L. M. i dr. sud je ukinuo prvostupanjsku osudu upravo na tom temelju - naime, iako je uporaba sile i prijetnji ove žrtve trgovine ljudima pretvorila u izrabljivače drugih, tužitelj nije razmotrio postoji li javni interes za njihovim progonom. ${ }^{79}$ Dakle, iz navedenoga se može zaključiti kako značajna dopuna modela krajnje nužde na kojem u suštini počiva (diskrecijska) odluka o

74 Podsjetimo, čl. 26. Konvencije od država zahtijeva da samo omoguće nekažnjivost žrtava trgovine ljudima (ne i nepokretanje kaznenog postupka) zbog njihova sudjelovanja u nezakonitim aktivnostima, u mjeri u kojoj su na to bile prisiljene (,to the extent that they have been compelled to do so").

75 Regina v. LM; YT; BT; DG, MB [2010.] EWCA Crim 2327., para 7.

76 Ibid., para. 8.

77 Regina v. LM; YT; BT; DG, MB [2010.] EWCA Crim 2327.

78 Pri čemu je ipak postavljen vrlo visok prag u pogledu procjene nerazumnosti - ,,so unreasonable that no reasonable prosecutor acting reasonably could have come to [decision to prosecute]", Hoshi, B., ,The Trafficking Defence: A Proposed Model for the Non-Criminalisation of Trafficked Persons in International Law“", Groningen Journal of International Law, vol 1(2), 2013., 54-72, str. 65.

79 Regina v. LM; YT; BT; DG, MB [2010.] EWCA Crim 2327., para. 24-34. 
nekažnjavanju u Ujedinjenom Kraljevstvu ${ }^{80}$ leži u načelu javnog interesa. Naime, čak i kada ne postoje jasni dokazi prisile u smislu u kojem se može podvesti pod situaciju krajnje nužde (duress defence), ali kazneno djelo je vjerojatno počinjeno kao ishod ekstenzivno tumačene prisile proizašle iz trgovine ljudima, tužitelj bi trebao razmotriti postoji li javni interes za pokretanjem progona ili ne. $\mathrm{U}$ ovom kontekstu, prisilu na činjenje kaznenih djela valja tumačiti ekstenzivno na način da uključi sva tzv. sredstva trgovanja ljudima: dakle, uz silu ili prijetnju, i obmanu, prijevaru, otmicu te zlouporabu ovlasti ili teškog položaja ili odnosa ovisnosti. ${ }^{81}$ Pri ocjeni je li žrtva bila prisiljena počiniti kazneno djelo, tužitelj tako treba razmotriti je li počinitelj imao „stvarnu alternativu pokoravanju dominantnoj sili drugoga“. U takvim situacijama, kada postupanje žrtve trgovanja ljudima ipak nije moguće podvesti pod krajnju nuždu, načelno neće biti javnog interesa za progonom, osim ukoliko se radi o vrlo teškom kaznenom djelu ili ako postoje značajne otegotne okolnosti. ${ }^{82}$

U svakom slučaju, potreban je izravan nexus između počinjenih kaznenih djela i viktimizacije u kontekstu trgovanja ljudima, pri čemu sama činjenica da je počinitelj ranije bio žrtva trgovanja ljudima nije dostatna. ${ }^{83}$ Naime, da bi u obzir došlo nekažnjavanje, potrebno je da je kazneno djelo rezultat prisile (u širem smislu) kao obilježja trgovanja ljudima, pa naknadno činjenje kaznenih djela, nakon što je počinitelj trgovanja ljudima „napustio“ svoju žrtvu ili je ona od njega pobjegla, samo po sebi ne opravdava odustajanje od progona. Pa ipak, u predmetu protiv L., državljanke Ugande, također osuđene zbog krivotvorenog identifikacijskog dokumenta koji je koristila nedugo nakon što je njezina višegodišnja seksualna eksploatacija u Ujedinjenom Kraljevstvu prestala, žalbeni sud je, ukidajući prvostupanjsku presudu, ustanovio kako je djelo zapravo počinjeno „kao rezultat činjenice da je bila žrtva trgovine ljudima“ (eng. ,, arisen as a result of her being a victim of trafficking “) te kako je korištenje krivotvorene putovnice ,predstavljalo korak u procesu bijega“, iako je L. koristila krivotvorenu putovnicu nakon što

80 Više u Hoshi, op. cit. u bilj. 73.

81 Parosha C., The Application of the Non-Punishment Principle: A practical approach to assessing compulsion in cases involving children and adults https:/www.coe.int/t/dghl/monitoring/trafficking/ Source/PPTs_workshop/Presentation_Chandran.ppt. (20. prosinca 2015.).

82 CPS, Prosecution Policy and Guidance, Legal Guidance „H to K“ Human Trafficking and Smuggling, http://www.cps.gov.uk/legal/h_to_k/human_trafficking_and_smuggling/\#a16 (20. prosinca 2015.).

83 Regina v. LM; YT; BT; DG, MB [2010.] EWCA Crim 2327., par. 45. Y. T., Nigerijka koja je kao žrtva trgovine ljudima dovedena u Ujedinjeno Kraljevstvo u konkretnom slučaju je koristila krivotvorene dokumente kako bi se zaposlila u Ujedinjenom Kraljevstvu nedugo nakon što je seksualna eksploatacija prestala. Sud je u ovom predmetu naglasio razliku između statusa ilegalnog imigranta i žrtve trgovine ljudima, te naznačio kako bi krajnji ishod možda bio drugačiji da je Y. T. koristila krivotvorene dokumente u pokušaju da pobjegne od svog eksploatatora, no to ovdje nije bio slučaj. 
je već pobjegla ${ }^{84}$ Drugačije je sud odlučio u predmetu protiv Y. T., državljanke Nigerije koja je koristila krivotvorene dokumente radi zapošljavanja u Ujedinjenom Kraljevstvu nakon što je prestala biti žrtvom seksualne eksploatacije ${ }^{85}$ Različito tretiranje Y. T. i L. u gotovo identičnim situacijama ukazuje na potencijalne probleme u praksi kod isključivog oslanjanja na diskrecijsku procjenu tužitelja. Istovremeno, iz ovog predmeta jasno proizlazi potreba za proširenjem i nadopunom modela prisile tzv. posebnim kauzalnim modelom, što je, čini se, i engleski sud makar implicitno priznao.

\section{ZAKLJUČAK}

Na temelju iznijete analize, valja zaključiti da je teško zamisliv jedan univerzalni model koji bi uvijek bio mjerodavan u slučaju da žrtve trgovanja ljudima ostvare obilježja određenog kaznenog djela, a koji bi bio ujedno i pravedan. Ne može se, naime, isključiti odgovornost, kazna ili kazneni progon za sva kaznena djela koja počini žrtva jer to bi u nekim situacijama moglo dovesti do rezultata koji se ne bi mogao smatrati pravednim. Stoga, valja se prikloniti mješovitom modelu na način da se kombiniraju klasični instituti općeg dijela kaznenog prava sa specijalnom odredbom koja bi bila regulirana u posebnom dijelu. Među općim odredbama, u prvom je redu primjenjiva krajnja nužda, ali u nekim situacijama mogu se primijeniti i drugi instituti (npr. dijete mlađe od 14 godina nije kazneno odgovorno; žrtva smije u nužnoj obrani usmrtiti svodnika koji ju je počeo silovati). Specijalna odredba bi trebala biti utemeljena na trgovanju ljudima kao uzroku činjenja kaznenog djela od strane žrtve, a bila bi primjenjiva na sve ostale slučajeve koje nisu pokrivene institutima općeg dijela. Time se zadržava i pravno-dogmatska dosljednost kaznenog zakonodavstva, jer nije potrebno regulirati nešto u posebnom dijelu što je već regulirano općim odredbama s istom pravnom posljedicom. Osim toga, rezultati analize poredbenopravne prakse ukazuju na to da je dio slučajeva žrtava trgovanja ljudima kao počinitelja kaznenih djela moguće rješavati putem primjene tužiteljske diskrecije. Potonja diskrecija je tipična za anglosaksonske pravne sustave, ali se posebnom regulativom može ugraditi i u načelo oportuniteta kaznenog progona, koje predstavlja iznimku od načela legaliteta u kontinentalnoeuropskim zemljama.

Ipak, s obzirom na kompleksnost problema pravne regulacije nekažnjivosti žrtava trgovanja ljudima, ova problematika zahtijeva daljnja istraživanja u

${ }^{84}$ Regina v. L, HVN, THN, T, [2013.] EWCA Crim 991., par. 74.

85 Supra bilj. 79. 
budućnosti kako bi se harmonizirao pristup ovom problemu ne samo među europskim državama, nego i šire.

\section{IMPUNITY FOR HUMAN TRAFFICKING VICTIMS IN CROATIA - LEGAL STANDARD AS A FICTION OR REALITY}

This article deals with one of the most vexing legal issues in context of trafficking in persons - that of non-punishment of trafficked persons for the offences they have committed in connection with or as a result of being trafficked. The conclusions are based on a comprehensive study of the socalled non-punishment clause in binding international documents (Council of Europe Convention, EU Directive, etc.) and soft law (e.g. UN Office of the High Commissioner for Human Rights, Recommended Principles and Guidelines on Human Rights and Human Trafficking, E/2002/68/), as well as on its implementation in comparative law and practice. Scarce (comparative) case law reveals deficiencies in existing framework and the necessity to address the issue of non-punishment of victims of trafficking in unambiguous manner, either through introduction of explicit nonpunishment clause or through instructive set of criteria, such are those established for the Crown Prosecution Service in UK.

Against this background and taking into account various approaches in comparative law, this article proposes a model for the non-criminalisation of trafficked persons in Croatia. It provides a set of guidelines foremost for the prosecutors and judges in order to help them strike an appropriate balance between fundamental principles of Croatian legal system and rights of people that are essentially victims, and not perpetrators.

Key words: Human trafficking, impunity, victims, Croatia 